\title{
PEMURNIAN PARSIAL EKSTRAK KASAR SELULASE BACILLUS CIRCULANS DENGAN METODA PENGENDAPAN ASETON
}

\section{PARTIAL PURIFICATION OF CRUDE EXTRACTS OF CELLULASE OF BACILLUS CIRCULANS WITH ACETON PRECIPITATION METHODS}

\author{
Iqbal Achmad Sabilla dan Evi Susanti* \\ Jurusan Kimia FMIPA Universitas Negeri Malang \\ email: evi.susanti.fmipa@um.ac.id
}

Received 9 May 2019

Accepted 28 June 2018

\begin{abstract}
Abstrak
Tujuan penelitian ini adalah untuk mengetahui tingkat kemurnian hasil pengendapan ekstrak kasar selulase Bacillus circulans pada berbagai kejenuhan aseton; pengaruh waktu pengendapan terhadap tingkat kemurnian hasil pengendapan pada kejenuhan aseton optimum; dan stabilitas waktu penyimpanan fraksi optimum pada suhu $0^{\circ} \mathrm{C}$ selama $0,1,4$ dan 7 hari. Aktivitas selulase diukur berdasarkan kenaikan kadar gula pereduksi yang dihasilkan pada substrat kertas Whatman no 1. Penentuan kadar gula pereduksi menggunakan metode SomogyNelson. Kadar protein ditentukan dengan metode Lowry. Tingkat kemurnian enzim merupakan perbandingan aktivitas spesifik enzim setelah pemurnian dengan sebelum pemurnian.Tingkat kemurnian hasil pengendapan ekstrak kasarBacillus circulans mengalami peningkatan pada kejenuhan aseton ( $33 \%),(41,1 \%)$ dan $(50 \%)$ kemudian menurun pada kejenuhan $(60 \%)$ dan (67\%). Fraksi yang aktivitas spesifik tertinggi adalah pada tingkat kejenuhan aseton $50 \%$, dengan tingkat kemurnian rata-rata 63,61 \pm 0,141 kali ekstrak kasar dan perolehan protein kembali rata-rata $76,85 \pm 7,99 \%$. Waktu pengendapan tidak berpengaruh terhadap tingkat kemurnian hasil pengendapan ekstrak kasar selulase Bacillus circulans pada kejenuhan aseton optimum.Selulase hasil pengendapan dengan aseton memiliki stabilitas yang kurang baik pada suhu $\pm 0^{\circ} \mathrm{C}$ karena menurun sebesar $41,1 \%$ pada hari pertama dan $88,2 \%$ pada hari ketujuh setelah penyimpanan. Perlu dikaji stabilitas selulase pada suhu penyimpanan yang lebih rendah untuk meningkatkan lama waktu simpannya.
\end{abstract}

Kata kunci: selulase, Bacillus circulans, pengendapan, aseton.

\begin{abstract}
The aims of this study were to determine the purity level of precipitations of cellulases of Bacillus circulans at various saturation of acetone; the effect of precipitation time on the purity level of the precipitations at optimum acetone saturation; and the stability of the storage time of the optimum fraction at $0{ }^{\circ} \mathrm{C}$ for $0,1,4$ and 7 days. The activity of cellulase was measured based on the increased of reducing sugar levels produced from hydrolysed of Whatman paper as substrate. The reducing sugar levels were determined with the Somogy-Nelson method. Protein levels are determined with the Lowry method. The purity level of the enzyme is a comparison of specific enzyme activity after and before purification. The purity level of
\end{abstract}


precipitations of cellulose of Bacillus circulans has increased in saturation of acetone (33\%), $(41.1 \%)$ and $(50 \%)$ then decreases in saturation $(60 \%)$ and $(67 \%)$. The highest cellulase specific activity fraction was at $50 \%$ acetone saturation level, with an average purity level of $63.61 \pm$ 0.141 times crude extract and yield protein recovery an average of $76.85 \pm 7.99 \%$. The precipitation time did not affect the purity level of the precipitations at optimum acetone saturation. The precipitations had low storage stability at $\pm 0{ }^{\circ} \mathrm{C}$ because its cellulase activity decreased by $41.1 \%$ on the first day and $88.2 \%$ on the seventh day after storage. The stability of cellulose at lower temperatures needs to be assessed to increase the storage life of cellulose.

The keywords: cellulose, Bacillus circulans, precipitation, aceton

\section{Pendahuluan}

Selulase merupakan enzim yang menghidrolisis ikatan $\beta$-1,4-glikosidik dalam rantai selulosa menjadi gula pereduksi, dikelompokkan menjadi endo$\beta$-glukanase atau CMCase(EC 3.2.1.4) adalah selulase yang memutus secara acak bagian dalam rantai selulosa; ekso- $\beta$ glukanase atau avicelase (EC 3.2.1.91) mengkatalisis pemutus rantai selulosa dari ujung rantai selulosa, baik ujung reduksi maupun non-reduksi; dan $\beta$-glukosidase (EC 3.2.1.21) mengkatalisis hidrolisis selobiosa dan rantai pendek selooligosakarida menjadi glukosa (Lian et al., 2014).

Selulase menjadi enzim industri yang memiliki nilai komersial tinggi karena banyak digunakan dalam berbagai industri, antara lain tekstil, kertas dan pulp, makanan serta pakan ternak. Selulase juga sangat dibutuhkan dalam proses produksi energi alternatif yaitu biokonversi selulosa menjadi bioetanol (Mendenez et al., 2015).

Selulase dapat diisolasi dari mikroorganisme, hewan, dan tumbuhan. Mikroorganisme terutama bakteri dapat memproduksi selulase secara cepat dan dalam jumlah yang banyak. Hal ini sesuai dengan pernyataan Aruwajoye $d k k$ (2014) \& Menendez $d k k$ (2015) bahwa selulase yang diisolasi dari bakteri memiliki beberapa keuntungan, yaitu pertumbuhannya cepat, biaya yang murah, memiliki keberagaman gen dan mampu beradaptasi terhadap variasi kondisi produksi sehingga isolasi selulase dari bakteri merupakan salah satu strategi yang terbaik untuk meningkatkan produksi selulase.

Salah satu bakteri penghasil selulase adalah spesies Bacillus khususnya Bacillus circulans. Susanti (2011) melaporkan bahwa kondisi optimum produksi selulase dari Bacillus circulans dalam media garam Berg adalah $\mathrm{pH}=9,0$, konsentrasi avicel sebagai induser sebesar $0,5 \%$, dan waktu inkubasi 5 hari dengan kecepatan pengocokan $85 \mathrm{rpm}$ dalam shaker water bath. Pada kondisi tersebut aktivitas CMCase dan avicelase yang dihasilkan sebesar 111,11 Unit/mL dan 55,56 Unit/mL. Penggunaan 0,5\% ampas tebu sebagai sumber karbon dan induser dalam medium produksinya mampu menghasilkan aktivitas CMCase dan avicelase sebesar 405,48 Unit/mL dan 309,39 Unit/mL (Rahmadani \& Susanti, 2012).

Stabilitas ekstrak kasar dan aktivitas enzim akan meningkat seiring dengan meningkatnya tingkat kemurnian enzim. Proses pemurnian terhadap ekstrak kasar enzim penting untuk dilakukan. Ekstrak kasar selulase umumnya memiliki stabilitas yang rendah karena masih mengandung 
kontaminan berupa protein lain, salah satunya adalah protease yang dapat mendegradasi selulase yang diinginkan. Pemurnian suatu enzim dapat memanfaatkan sifat-sifat enzim sebagai protein.Tahap awal pemurnian yang umum dilakukan adalah pemekatan ekstrak kasar enzim. Tahap ini dapat dilakukan dengan beberapa metode yakni pengendapan amonium sulfat, pelarut organik, dan pada titik isoelektrik (Rosenberg, 1996).

Metode pengendapan pelarut organik didasarkan pada perbedaan kelarutan protein dalam pelarut organik. Pemilihan pelarut organik sebagai agen presipitasi karena prosesnya sederhana, sangat efektif, dan murah (Rosenberg, 1996; Trentini $d k k$, 2015). Penambahan pelarut organik umumnya menurunkan konstanta dielektrik larutan sehingga gaya elektrostatik yang melindungi gugus fungsi yang polar dan bermuatan pada protein menurun dan interaksi tarik menarik antar molekul protein meningkat yang mengakibatkan protein mengendap. Metode pengendapan pelarut organik dipengaruhi oleh beberapa faktor, diantaranya yaitu konsentrasi atau kejenuhan pelarut, $\mathrm{pH}$ dan waktu inkubasi setelah penambahan pelarut (Trentini $d k k$, 2015; Burgess \& Deuthcher, 2009; Scopes, 1987). Pemekatan ekstrak kasar selulase dari Bacillus circulans menggunakan metode pengendapan pelarut organik khususnya aseton belum pernah dilakukan sehingga pada penelitian ini dipelajari bagaimana pengaruh \% kejenuhan dan waktu pengendapan terhadap tingkat kemurnian dan perolehan protein kembali dan stabilitas hasil pemurniannya pada suhu $0^{\circ} \mathrm{C}$.

\section{Metoda Penelitian}

Alat dan Bahan

Bahan-bahan yang digunakan terdiri dari bahan kimia berderajat p.a dan ampas tebu. Alat-alat yang digunakan dalam penelitian Online ISSN: 2528-0422 terbagi menjadi peralatan gelas dan non gelas. Peralatan gelas terdiri dari cawan petri, tabung reaksi, gelas arloji, batang pengaduk, pipet tetes, pipet ukur $1 \mathrm{~mL}$, gelas ukur 10 dan $100 \mathrm{~mL}$, corong kaca, gelas beaker 50, 250 dan $500 \mathrm{ml}$, Erlenmeyer 50 dan $250 \mathrm{ml}$, labu takar 50,100, 200, 250 dan 500 mL. Peralatan non gelas terdiri dari indikator universal, jarum ose, microtube, magnetik stirer, neraca analitik (ACIS), enkase, autoklaf, incubator (Eyela tipe SLI-600ND), Uni Termo Shaker (EyelaNTS-1300), refrigerator centrifuge (Dynamica), lemari pendingin (SHARP VR-D180) dan spektrofotometer (Spekronik-20).

\section{Peremajaan Bacillus cirulans}

Peremajaan biakan murni bakteri Bacillus circulans dilakukan secara aseptis ke dalam medium nutrien agar (NA) dan diinkubasi pada suhu $37{ }^{0} \mathrm{C}$ selama semalam.

Produksi ekstrak kasar selulase Bacillus circulans

Sebanyak 5 ose Bacillus circulans dari medium nutrien agar diinokulasikan ke dalam $10 \mathrm{ml}$ medium nutrien cair secara aseptis, diinkubasi semalam pada suhu 37 ${ }^{\circ} \mathrm{C}$ dan $100 \mathrm{rpm}$ hingga mencapai OD $\approx 0,344$ dan diperoleh biakan starter. Sebanyak 2 $\mathrm{mL}$ starter diinokulasikan secara aseptis ke dalam $100 \mathrm{~mL}$ medium produksi. Kultur biakan diinkubasi pada $37{ }^{\circ} \mathrm{C}$ dan $85 \mathrm{rpm}$ selama 5 hari, disentrifugasi $3000 \mathrm{rpm}$ selama 20 menit. Supernatan yang diperoleh merupakan ekstrak kasar selulase.

Pengendapan Ekstrak Kasar Selulase dari Bacillus circulans pada Berbagai Kejenuhan Aseton

Pemurnian parsial ekstrak kasar selulase dengan metode pengendapan aseton berdasarkan kejenuhan aseton dilakukan dengan cara ekstrak kasar selulase Bacillus 
circulans yang telah ditambah EDTA hingga konsentrasi total $5 \mathrm{mM}$ dialikuot dengan volume yang sama menjadi beberapa bagian, masing-masing ditambahkan aseton absolut dingin sedikit demi sedikit dengan konsentrasi atau kejenuhan aseton (perbandingan volume ekstrak kasar dengan volume aseton absolut dingin) sebesar $33 \%(1: 0,5), 41,1 \%(1: 0,7)$, $50 \%(1: 1), 60 \%(1: 1,5)$, dan $67 \%(1: 2)$ sambil diaduk secara perlahan dalam penangas es menggunakan pengaduk magnet. Campuran dibiarkan selama semalam dalam freezer lemari pendingin untuk memaksimalkan pengendapan. Enzim yang mengendap dipisahkan dengan cara sentrifugasi dingin selama 30 menit dengan kecepatan $10.000 \mathrm{rpm}$. Residu atau pelet yang dihasilkan dari masing-masing fraksi dilarutkan dengan buffer fosfat $0,2 \mathrm{M}$ $\mathrm{pH}$ 7,0 sehingga suspensi yang dihasilkan adalah fraksi I (33 \%), fraksi II (41,1\%), fraksi III (50 \%), fraksi IV (60\%) dan fraksi $\mathrm{V}(67 \%)$. Tiap fraksi ditentukan aktivitas selulase dan kadar protein.

Pengaruh Waktu Pengendapan Terhadap Tingkat Kemurnian Hasil Fraksinasi Ekstrak Kasar Selulase dari Bacillus Circulans pada Kejenuhan Aseton Optimum

Pengamatan pengaruh waktu terhadap proses pengendapan ekstrak kasar protein menggunakan aseton dilakukan dengan cara ekstrak kasar selulase Bacillus circulans yang telah ditambah EDTA hingga konsentrasi total $5 \mathrm{mM}$ dialikuot dengan volume yang sama menjadi beberapa bagian, masing-masing ditambahkan aseton absolut dingin sebanyak volume tertentu (fraksi optimum dari percobaan sebelumnya) sedikit demi sedikit sambil diaduk secara perlahan dalam penangas es menggunakan pengaduk magnet. Campuran dibiarkan dalam freezer lemari pendingin selama variasi waktu 1, 3, dan 23 jam. Enzim yang mengendap dipisahkan dengan cara sentrifugasi dingin selama 30 menit dengan kecepatan $10.000 \mathrm{rpm}$. Residu atau pelet yang dihasilkan dari masing-masing fraksi dilarutkan dengan $0,2 \mathrm{M}$ buffer sodium fosfat $\mathrm{pH} \mathrm{7,0} \mathrm{dingin.} \mathrm{Tiap} \mathrm{fraksi}$ ditentukan aktivitas selulase dan kadar protein.

Uji stabilitas penyimpanan hasil pengendapan ekstrak kasar selulase Bacillus circulans pada suhu $\pm 0^{\circ} \mathrm{C}$

Hasil pengendapan disimpan dalam freezer lemari pendingin SHARP VR-D180 $\left( \pm 0{ }^{\circ} \mathrm{C}\right)$ selama 7 hari. Ditentukan aktivitas selulase total dan kadar protein selama penyimpanan pada hari ke 0,1 , 4, dan 7 hari.

\section{Uji aktivitas selulase}

Penentuan aktivitas enzim merujuk Susanti (2011) dengan modifikasi waktu inkubasi dari 120 menjadi 60 menit. Berikut langkah kerja yang dilakukan yaitu disiapkan 4 tabung reaksi, masing-masing diisi $2 \mathrm{~mL}$ enzim, $2 \mathrm{~mL}$ substrat $1 \%$ dalam bufer fosfat $\mathrm{pH} 7$ dan $1 \mathrm{~mL}$ buffer fosfat $\mathrm{pH} 7$, diinkubasi pada $45^{\circ} \mathrm{C}$ selama 60 menit. Jumlah substrat yang terhidrolisis menjadi gula pereduksi ditentukan dengan metode Somogyi-Nelson. Aktivitas selulase ditentukan dengan cara yang dijelaskan di atas dengan menggunakan substrat kertas saring Whattman No.1. Pembuatan kontrol reaksi enzimatis dilakukan dengan mematikan enzim sebelum diinkubasi dengan substrat. Sebanyak $2 \mathrm{~mL}$ enzim dipanaskan selama 5 menit pada suhu $95^{\circ} \mathrm{C}$, ditambahkan $2 \mathrm{~mL}$ substrat $1 \%$ dalam bufer fosfat $\mathrm{pH} 7$ dan $1 \mathrm{~mL}$ buffer fosfat $\mathrm{pH} 7$, diinkubasi pada $45^{\circ} \mathrm{C}$ selama 60 menit. Perlakuan kontrol dan sampel dilakukan bersamaan. Aktivitas selulase dinyatakan sebagai Unit/mL. Unit aktivitas enzim selulase adalah jumlah glukosa yang lepas $(\mu \mathrm{g})$ per $\mathrm{mL}$ enzim $(\mathrm{U} / \mathrm{mL})$ per jam waktu inkubasi enzim substrat pada kondisi percobaan. Pengukuran aktivitas enzim 
dilakukan dengan mengkonversi nilai absorbansi pada penentuan kadar glukosa ke kurva standar glukosa sehingga diperoleh konsentrasi. Data tersebut dimasukkan ke persamaan berikut. Aktivitas selulase $=\frac{x}{q} \cdot f_{p}$

Dimana:

$\mathrm{x}=$ konsentrasi gula pereduksi (ppm)

$f_{p}=$ faktor pengenceran yaitu perbandingan volume total reaksi dalam tabung dengan volume enzim sebesar 2,5

$\mathrm{q}=$ waktu reaksi (jam)

Penentuan kadar gula pereduksi dengan metode Somogy-Nelson

Sebanyak $1 \mathrm{~mL}$ sampel dan masingmasing $1 \mathrm{~mL}$ larutan glukosa yang mengandung 0 (blanko), 50, 100, 150 dan 200 ppm glukosa, ditambah $1 \mathrm{~mL}$ pereaksi Nelson, diaduk hingga homogen, dipanaskan dalam penangas air mendidih selama 20 menit. Setelah dingin (pada suhu ruang) ditambah $1 \mathrm{~mL}$ perekasi arsenomolibdat, dan $7 \mathrm{~mL}$ aquades untuk mengurangi kepekatan. Absorbansi larutan diukur pada panjang gelombang $540 \mathrm{~nm}$. Data konsentrasi larutan gula standar dan absorbansinya digunakan untuk membuat kurva standar glukosa. Kadar glukosa ditentukan dengan menginterpolasikan nilai absorbansi yang diperoleh ke persamaan linier kurva standar glukosa.

\section{Pengukuran kadar protein dengan metode Lowry}

Sebanyak 0,5 larutan protein standar yang mengandung 0 (blanko), 20, 40, 60, 80, $100 \mu \mathrm{g}$ BSA (Bovine Serum Albumin), ditambah 2,5 $\mathrm{mL}$ pereaksi biuret, diaduk hingga homogen. Campuran diinkubasi pada suhu kamar tepat 10 menit. Setelah itu campuran ditambahkan $0,25 \mathrm{~mL}$ Folin Ciocalteu, dihomogenkan dengan vortex, dan diinkubasi pada suhu kamar tepat 30 menit. Nilai absorbansi larutan diukur pada panjang gelombang $750 \mathrm{~nm}$. Data konsentrasi BSA dan absorbansinya digunakan untuk membuat kurva standar protein. Kadar protein ditentukan dengan menginterpolasikan nilai absorbansi yang diperoleh ke persamaan linier kurva standar protein.

\section{Hasil dan Pembahasan}

Tingkat kemurnian selulase Bacillus circulans pada kejenuhan aseton $33 \%, 41,1$ $\%, 50 \%, 60 \%$, dan $67 \%$.

Hasil pemurnian parsial ekstrak kasar Bacillus circulans menunjukkan semakin tinggi tingkat kejenuhan aseton yang digunakan maka semakin besar total protein yang diperoleh (Tabel 1). Semakin banyak jumlah aseton absolut yang ditambahkan dalam larutan protein akan menurunkan nilai konstanta dielektrik larutan, akibatnya gaya elektrostatik yang melindungi gugus fungsi yang polar dan bermuatan pada protein menurun dan interaksi tarik menarik antar molekul protein meningkat sehingga terbentuk agregat protein. Namun, tidak terjadi pola yang sama pada aktivitas selulase hasil pemurnian (Tabel 1). Aktivitas selulase meningkat pada tingkat kejenuhan aseton $33 \%$ (fraksi I) hingga 50 $\%$ (fraksi III), tetapi pada tingkat kejenuhan etanol $60 \%$ (fraksi IV) dan $67 \%$ (fraksi V) aktivitas selulase mengalami penurunan. 
Tabel 1. Tingkat Kemurnian Fraksi Selulase dari Bacillus circulans Hasil Pengendapan pada Berbagai Tingkat Kejenuhan Aseton.

\begin{tabular}{ccccccc}
\hline Fraksi & Volume & $\begin{array}{c}\text { Total Protein } \\
(\mathbf{m g})\end{array}$ & $\begin{array}{c}\text { Aktivitas Total } \\
(\text { Unit })\end{array}$ & $\begin{array}{c}\text { Aktivitas Spesifik } \\
(\text { Unit/mg) }\end{array}$ & $\begin{array}{c}\text { Perolehan } \\
\text { Kembali }(\%)\end{array}$ & $\begin{array}{c}\text { Tingkat } \\
\text { Kemurnian }\end{array}$ \\
\hline $\mathbf{E K}$ & 20 & $3,726 \pm 0,033$ & $200,00 \pm 0,000$ & $53,69 \pm 0,961$ & $100,00 \pm 0,000$ & 1 \\
$\mathbf{( 3 3 \% )}$ & 3 & $0,043 \pm 0,002$ & $116,25 \pm 15,909$ & $2732,015 \pm 56,160$ & $58,10 \pm 7,919$ & 51 \\
$\mathbf{( 4 1 , 1 \% )}$ & 3 & $0,044 \pm 0,003$ & $135 \pm 21,213$ & $3062,5 \pm 88,380$ & $67,50 \pm 10,606$ & 57 \\
$\mathbf{( 5 0 \% )}$ & 3 & $0,045 \pm 0,0028$ & $153,75 \pm 15,90$ & $3421 \pm 76,36$ & $76,85 \pm 7,990$ & 64 \\
$(\mathbf{6 0 \%})$ & 3 & $0,103 \pm 0,0014$ & $48,75 \pm 5,303$ & $472,77 \pm 38,50$ & $24,35 \pm 2,616$ & 9 \\
$(\mathbf{6 7 \%})$ & 3 & $0,133 \pm 0,0049$ & $33,75 \pm 5,303$ & $255,945 \pm 58,92$ & $16,85 \pm 2,616$ & 5 \\
\hline
\end{tabular}

*Nilai yang tertera diatas merupakan nilai rata-rata. \pm SD dari dua ulangan

Penurunan aktivitas selulase pada fraksi IV dan $\mathrm{V}$ diduga karena sebagian selulase mengalami perubahan konformasi menjadi terdenaturasi dan kehilangan aktivitasnya. Perubahan konformasi baik struktur sekunder, tersier, maupun kuaterner dikenal dengan denaturasi protein pada penelitian ini terjadi karena perubahan kepolaran lingkungan disekitar protein. Sebelum penambahan aseton lingkungan protein adalah lingkungan hidrofilik sehingga residu-residu dengan rantai samping gugus hidofilik mendominasi permukaan protein dan residu-residu dengan rantai samping gugus hidrofobik terdapat di bagian dalam. Setelah penambahan aseton berlebih lingkungan menjadi nonpolar yang memicu terbukanya struktur protein sehingga residu-residu dengan rantai samping gugus hidrofobik yang awalnya terdapat di bagian dalam menjadi terbuka sehingga struktur protein yang awalnya globular berubah menjadi acak.

Peningkatan total protein dan penurunan aktivitas total selulase pada fraksi IV dan V menurunkan juga nilai aktivitas spesifik dan tingkat kemurniannya. Maka dapat disimpulkan bahwa pemurnian parsial ekstrak kasar Bacillus circulans dengan metoda pengendapan aseton optimum pada tingkat kejenuhan aseton $50 \%$ dengan tingkat kemurnian 64 kali dibandingkan ekstrak kasar dan nilai perolehan protein kembali $76,85 \pm 7,99 \%$.

Pengaruh waktu pengendapan terhadap tingkat kemurnian fraksi selulase optimum

Burgess \& Deuthcher (2009:297) menyatakan bahwa setelah penambahan pelarut organik dalam larutan protein, selanjutnya campuran dibiarkan sedikitnya 15 menit agar mencapai kesetimbangan dan protein mengendap secara maksimal. Dalam penelitiannya, Gemili et al (2007) melaporkan bahwa penerapan waktu inkubasi yang tepat dalam proses pemurnian menggunakan metode pengendapan aseton berpengaruh terhadap banyaknya hasil pemurnian yang diperoleh. Maka pada penelitian ini dilakukan variasi waktu pengendapan setelah penambahan aseton yaitu 1, 3, dan 23 jam. Pemilihan waktu tersebut untuk mengetahui pengaruh waktu inkubasi pada waktu singkat (1 jam), sedang (3 jam), dan lama (23 jam). 
Tabel 2. Pengaruh Waktu Pengendapan Terhadap Tingkat Kemurnian Hasil Fraksinasi Selulase dari Bacillus circulans pada Kejenuhan Aseton Optimum

\begin{tabular}{llllll}
\hline Jam ke- & $\begin{array}{l}\text { Aktivitas } \\
\text { Total }\end{array}$ & $\begin{array}{l}\text { Total Protein } \\
(\mathbf{m g})\end{array}$ & $\begin{array}{l}\text { Aktivitas Spesifik } \\
\text { (Unit/mg) }\end{array}$ & $\begin{array}{l}\text { Perolehan } \\
\text { Kembali (\%) }\end{array}$ & $\begin{array}{l}\text { Tingkat } \\
\text { Kemurnian }\end{array}$ \\
\hline EK & 150,0 & 3,530 & 42,49 & 100 & 1 \\
$\mathbf{1}$ & 90,0 & 0,038 & 2368,42 & 60 & 56 \\
$\mathbf{3}$ & 112,5 & 0,041 & 2743,90 & 75 & 65 \\
$\mathbf{2 3}$ & 112,5 & 0,040 & 2812,50 & 75 & 66 \\
\hline
\end{tabular}

Hasil penelitian menunjukkan bahwa aktivitas spesifik, perolehan kembali, dan tingkat kemurnian enzim antara waktu inkubasi pengendapan 1, 3, dan 23 jam hampir sama (Tabel 2), sehingga dapat dikatakan bahwa waktu inkubasi tidak berpengaruh terhadap peningkatan kemurnian selulase yang dimurnikan dengan pengendapan aseton.

Stabilitas waktu penyimpanan hasil fraksi optimum pada suhu $0^{\circ} \mathrm{C}$

Ekstrak kasar selulase memiliki stabilitas yang rendah apabila disimpan dalam waktu yang lama sehingga perlu dilakukan pemekatan atau pemurnian awal. Penelitian ini menggunakan metode pengendapan aseton untuk memurnikan ekstrak kasar selulase Bacillus circulans sehingga dapat diperoleh enzim selulase dengan tingkat kemurnian tinggi dan diharapkan memiliki stabilitas yang baik. Fraksi optimum hasil pemurnian (pelet hasil pengendapan yang diresuspensi dalam buffer fosfat $\mathrm{pH}$ 7) dengan metode pengendapan aseton disimpan selama variasi waktu $0,1,4$, dan 7 hari dalam freezer lemari pendingin SHARP VR-D180. Hasil uji stabilitas menunjukkan bahwa aktivitas total enzim menurun $41,1 \%$ pada hari pertama dan $47 \%$ pada hari keempat setelah penyimpanan, dan pada hari ketujuh menurun menjadi 88 $\%$ jika dibandingkan dengan aktivitas selulase pada awal penyimpanan. Hal ini diduga karena terjadi degradasi dan/atau denaturasi selulase selama penyimpanan. Degradasi selulase diduga karena aktivitas protease, yang juga terendapkan selama proses pengendapan, selama proses penyimpanan maupun selama proses resuspensi pelet sebelum pengujian stabilitas penyimpanan dilakukan. Denaturasi selulase diduga berasal dari air yang ditambahkan sebelum penyimpanan. Molekul air dapat mempengaruhi konformasi protein selama dalam proses pembekuan (freeze) dan pencairan sampel (thawing) sehingga menyebabkan denaturasi. Denaturasi selulase juga kemungkinan terjadi karena adanya perubahan konformasi atau folding akibat perubahan lingkungan sekitar enzim. Hal ini disebabkan karena pelet enzim hasil sentrifugasi belum benar-benar bebas dari aseton sehingga ketika diresuspensi dengan larutan buffer fosfat $\mathrm{pH} 7$ lingkungan sekitar enzim berubah dari hidrofobik menjadi hidrofilik 
Tabel 3. Aktivitas Fraksi Selulase Optimum selama Penyimpanan dalam freezer Lemari Pendingin SHARP VR-D180

\begin{tabular}{lllll}
\hline $\begin{array}{l}\text { Variasi } \\
\text { Waktu } \\
\text { (hari) }\end{array}$ & Aktivitas Total $(\mathbf{U})$ & \multicolumn{3}{l}{ \% penurunan } \\
\cline { 2 - 5 } & Peneliti & Islami (2016) & Peneliti & Islami (2016) \\
\hline $\mathbf{0}$ & 127,5 & 375 & 0 & 0 \\
$\mathbf{1}$ & 75 & 75 & 41,1 & 80,0 \\
$\mathbf{4}$ & 67,5 & 75 & 47,0 & 80,0 \\
$\mathbf{7}$ & 15 & 37,5 & 88,2 & 90,0 \\
\hline
\end{tabular}

Uji stabilitas penyimpanan hasil fraksi optimum pengendapan dengan aseton lebih baik dibandingkan dengan stabilitas penyimpanan fraksi optimum hasil pemurnian selulase dengan metode pengendapan etanol dalam kondisi yang sama (Islami, 2016). Fraksi optimum hasil pengendapan dengan etanol mengalami penurunan sebesar $80 \%$ pada hari pertama, $80 \%$ pada hari keempat dan $90 \%$ pada hari ketujuh (Tabel 3). Maka dapat dikatakan bahwa kestabilan fraksi optimum selulase hasil pemurnian dengan metode pengendapan aseton lebih baik dibandingkan dengan hasil pemurnian dengan metode pengendapan etanol. Pendapat ini juga didukung oleh data lainnya yaitu perolehan kembali dan tingkat kemurnian pada masing-masing fraksi optimum. Fraksi optimum aseton (fraksi dengan tingkat kejenuhan aseton $50 \%$ ) memiliki perolehan kembali dan tingkat kemurnian enzim rata-rata yaitu $76,85 \%$ dan 64 kali ekstrak kasar selulase, sedangkan fraksi optimum etanol (fraksi dengan tingkat kejenuhan etanol 50\%) perolehan kembali dan tingkat kemurnian enzim rata-rata hanya 65,14\% dan 49 kali ekstrak kasar selulase (Tabel 4). Berdasarkan uraian di atas menunjukkan bahwa metode pengendapan aseton cukup berpotensi sebagai metode pemurnian enzim, akan tetapi perlu dicari suatu kondisi atau perlakuan untuk meningkatkan stabilitas fraksi optimumnya.

Tabel 4. Perbandingan Hasil Pemurnian Ekstrak Kasar Selulase Bacillus circulans dengan Metode Pengendapan Aseton dan Metode Pengendapan Etanol

\begin{tabular}{lllll}
\hline \multirow{2}{*}{ Fraksi Optimum } & \multicolumn{2}{l}{ Perolehan Kembali (\%) } & \multicolumn{2}{l}{ Tingkat Kemurnian } \\
\cline { 2 - 5 } & Peneliti & Islami (2016) & Peneliti & Islami (2016) \\
\hline Fraksi optimum & $76,85 \%$ & $65,14 \%$ & 63.61 & 49,17 \\
\hline
\end{tabular}

\section{Kesimpulan}

Tingkat kemurnian hasil pengendapan ekstrak kasar Bacillus circulans mengalami peningkatan pada kejenuhan aseton (33\%), (41,1\%), dan $(50 \%)$ kemudian menurun pada kejenuhan aseton (60\%) dan (67\%). Fraksi yang memiliki aktifitas spesifik tertinggi adalah pada tingkat kejenuhan aseton $50 \%$ dengan tingkat kemurnian rata-rata $63,61 \pm 0,141$ kali ekstrak kasar dan perolehan kembali rata-rata $76,85 \pm 7,99 \%$. Waktu pengendapan tidak berpengaruh terhadap tingkat kemurnian hasil fraksinasi ekstrak kasar selulase Bacillus circulans pada kejenuhan aseton optimum. Selulase hasil pengendapan dengan aseton memiliki stabilitas yang cukup baik dalam lemari 
pendingin SHARP VR-D180 pada suhu \pm $0^{\circ} \mathrm{C}$ (freezer). Aktivitas selulase menurun

\section{Daftar Pustaka}

Aruwajoye, G. S., Omoboye, O. O., Daramola, I. O., \& Agboola, K. F. 2014. Extracellular cellulase production by Bacillus circulans isolated from decayed wood. International Journal of Academic Research in Applied Science, 3 (2): 18.

Burgess, R. R. \& Deutscher, M. P. 2009. Methods in Enzymology: Guide to Protein Purification, $2^{\text {nd }}$. London: Academic Press.

Gemili, S., Umdu, E. S., Yaprak, N., Ustok, F. I., Yener, F. Y. G., Gucbilmez, C. M., Altinkaya, S. A., \& Yemenicioglu, A. 2007. Partial Purification of Hen Egg White Lysozyme by Ethanol Precipitation Method and Determination of the Thermal Stability of Its Lyophilized Form. Turk J Agric For, 31: 125-134.

Islami, Lila S. 2016. Pengaruh Tingkat Kejenuhan dan Waktu Inkubasi Terhadap Kemurnian Selulase dari Bacillus Circulans yang Dimurnikan dengan Pengendapan Etanol Serta Stabilitasnya Selama Penyimpanan. Skripsi tidak diterbitkan. Malang: Jurusan Kimia FMIPA UM.

Lian, P., Guo, H. B., Smith, J. C., Wei, D. Q., \& Guo, H. 2014. Catalytic mechanism and origin of high activity of cellulase TmCel12A at high sebesar $41,1 \%$ pada hari pertama dan 88,2 $\%$ pada hari ketujuh setelah penyimpanan. temperature: a quantum mechanical/molecular mechanical study. Cellulose, 21: 937-949.

Menendez, E., Fraile, P. G., \& Rivas, R. 2015. Biotechnological applications of bacterial cellulases. AIMS Bioengineering, 2: 163-182.

Rahmadani, A. H. \& Susanti, E. 2012. Pemilihan dan Optimasi Konsentrasi Induser Alamiah serta Analisis Potensi Sistem Selulase dari Bacillus circulans untuk Mendegradasi Substrat Lignoselulosa. Jurnal Valensi, 3 (2).

Rosenberg, I. M. 1996. Protein Analysis and Purification: Benchtop Technique: Birkhauser.

Scopes, R. K. 1987. Protein Purification Principle and Practice, $2^{\text {nd }} e d$. New York: Springer-Verlag New York, Inc.

Susanti, E. 2011. Optimasi Produksi dan Karakterisasi Sistem Selulase dari Bacillus circulans strain Lokal dengan Induser Avicel. Jurnal ILMU DASAR, 12 (1): 40-49.

Trentini, M. M. S., Toniazzo, G., Zeni, J., Pili, J., Luccio, M. D. dan Valduga, E. 2015. Purification of Pectinases from Aspergillus niger ATCC 9642 by Ethanol Precipitation. Biocatalysis and Agricultural Biotechnology, 4: 315-320 